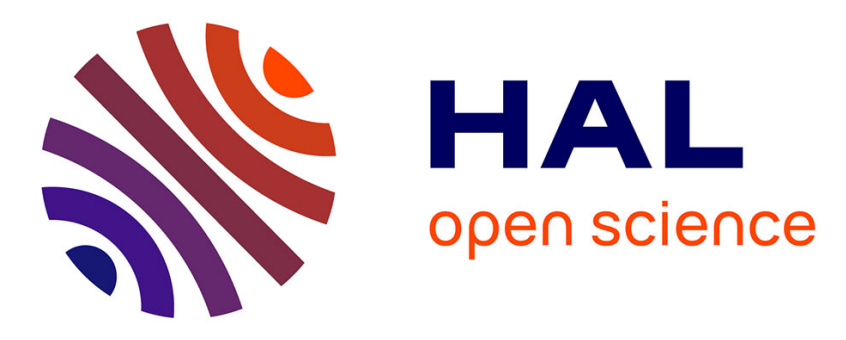

\title{
An analytic study of applying miller cycle to reduce nox emission from petrol engine
}

Yaodong Wang, Lin Lin, Antony P. Roskilly, Shengchuo Zeng, Jincheng

Huang, Yunxin He, Xiaodong Huang, Huilan Huang, Haiyan Wei, Shangping Li, et al.

\section{To cite this version:}

Yaodong Wang, Lin Lin, Antony P. Roskilly, Shengchuo Zeng, Jincheng Huang, et al.. An analytic study of applying miller cycle to reduce nox emission from petrol engine. Applied Thermal Engineering, 2007, 27 (11-12), pp.1779. 10.1016/j.applthermaleng.2007.01.013 . hal-00498945

\section{HAL Id: hal-00498945 https://hal.science/hal-00498945}

Submitted on 9 Jul 2010

HAL is a multi-disciplinary open access archive for the deposit and dissemination of scientific research documents, whether they are published or not. The documents may come from teaching and research institutions in France or abroad, or from public or private research centers.
L'archive ouverte pluridisciplinaire HAL, est destinée au dépôt et à la diffusion de documents scientifiques de niveau recherche, publiés ou non, émanant des établissements d'enseignement et de recherche français ou étrangers, des laboratoires publics ou privés. 


\section{Accepted Manuscript}

An analytic study of applying miller cycle to reduce nox emission from petrol engine

Yaodong Wang, Lin Lin, Antony P. Roskilly, Shengchuo Zeng, Jincheng Huang, Yunxin He, Xiaodong Huang, Huilan Huang, Haiyan Wei, Shangping Li, J Yang

PII: S1359-4311(07)00031-2

DOI: 10.1016/j.applthermaleng.2007.01.013

Reference: ATE 2070

\section{APPLIED}

THERMAL

ENGINEERING

To appear in:

Applied Thermal Engineering

Received Date: $\quad 5$ May 2006

Revised Date: $\quad 2$ January 2007

Accepted Date: $\quad 14$ January 2007

Please cite this article as: Y. Wang, L. Lin, A.P. Roskilly, S. Zeng, J. Huang, Y. He, X. Huang, H. Huang, H. Wei, S. Li, J. Yang, An analytic study of applying miller cycle to reduce nox emission from petrol engine, Applied Thermal Engineering (2006), doi: 10.1016/j.applthermaleng.2007.01.013

This is a PDF file of an unedited manuscript that has been accepted for publication. As a service to our customers we are providing this early version of the manuscript. The manuscript will undergo copyediting, typesetting, and review of the resulting proof before it is published in its final form. Please note that during the production process errors may be discovered which could affect the content, and all legal disclaimers that apply to the journal pertain. 


\title{
An Analytic Study of Applying Miller Cycle to reduce NOx
}

\section{Emission from Petrol Engine}

\author{
Yaodong Wang *,a, b, Lin Linc, Antony P. Roskilly ${ }^{\mathrm{a}}$, Shengchuo Zeng ${ }^{\mathrm{b}}$, Jincheng Huang ${ }^{\mathrm{b}}$, \\ Yunxin $\mathrm{He}^{\mathrm{b}}$, Xiaodong Huang ${ }^{\mathrm{b}}$, Huilan Huang ${ }^{\mathrm{b}}$, Haiyan Wei ${ }^{\mathrm{b}}$, Shangping Li ${ }^{\mathrm{d}}, \mathrm{J}^{\text {Yang }}{ }^{\mathrm{e}}$ \\ ${ }^{\text {a }}$ School of Marine Science and Technology, Newcastle University, Newcastle upon Tyne, NE1 7RU, \\ United Kingdom \\ ${ }^{\mathrm{b}}$ Mechanical Engineering College, Guangxi University, Nanning, Guangxi, 530004, China \\ ${ }^{c}$ Nanning College for Vocational Technology, Nanning, Guangxi, 530003, China \\ ${ }^{\mathrm{d}}$ Guangxi University of Technology, Liuzhou, 545006, China \\ ${ }^{\mathrm{e}}$ Mechanical Engineering College, University of Science and Technology Beijing, Beijing, China
}

\begin{abstract}
An analytic investigation of applying Miller cycle to reduce nitrogen oxides (NOx) emissions from a petrol engine is carried out. The Miller cycle used in the investigation is a Late Intake Valve Closing version. A detailed thermodynamic analysis of the cycle is presented. A comparison of the characters of Miller cycle with Otto cycle is presented. From the results of thermodynamic analyses, it can be seen that the application of Miller cycle is able to reduce the compression pressure and temperature in the cylinder at the end of compression stroke. Therefore, it lowers down the combustion temperature and NOx formation in engine cylinder. These results in a lower exhaust temperature and less NOx emissions compared with that of Otto cycle. The analytic results also show that Miller cycle ratio is a main factor to influence the combustion temperature, and then the NOx emissions and the exhaust temperature. The results from the analytic study are used to analyse and to compare

*Corresponding author: Dr Yaodong Wang, Tel: 0044191 2223522; Fax: 00441912225491

Email: yaodongwang2000@yahoo.com, y.d.wang@ncl.ac.uk
\end{abstract}


with the previous experimental results. An empirical formula from the previous experimental results that showed the relation of NOx emissions with the exhaust temperature at different engine speed is presented. The results from the study showed that the application of Miller cycle may reduce NOx emissions from petrol engine.

Key words: Petrol engine, Miller cycle, NOx emissions, analytic study

\section{Notations}

$\mathrm{C}_{\mathrm{v}} \quad$ Specific heat value at constant volume $(\mathrm{kJ} / \mathrm{kg} \mathrm{K})$

$\mathrm{C}_{\mathrm{p}} \quad$ Specific heat value at constant pressure $(\mathrm{kJ} / \mathrm{kg} \mathrm{K})$

cps Cycles per second

$i \quad$ Number of the cylinders

k Specific heat ratio

$m \quad$ Gas mass in the piston-cylinder

$\mathrm{P} \quad$ Pressure in the cylinder $(\mathrm{kPa})$

$\mathrm{P}_{\text {atm }}$ Ambient pressure ( $\left.\mathrm{kPa}\right)$

$\mathrm{P}_{\mathrm{e}} \quad$ Engine brake power $(\mathrm{kW})$

$\mathrm{Pi}$ Indicated power of engine $(\mathrm{kW})$

$q_{\text {in }}$ Heat input to the engine $(\mathrm{kJ} / \mathrm{kg})$

$q_{\text {out }}$ Heat rejected from the engine $(\mathrm{kJ} / \mathrm{kg})$

R Gas constant $(\mathrm{R}=0.2874 \mathrm{~kJ} / \mathrm{kg} \mathrm{K})$

$r_{\mathrm{M}} \quad$ Miller Cycle Ratio

$\mathrm{T} \quad$ Temperature in the cylinder $(\mathrm{K})$

$\mathrm{T}_{\text {atm }}$ Ambient temperature (K)

$\mathrm{T}_{\text {exh }}$ Exhaust temperature (K)

u Internal energy $(\mathrm{kJ} / \mathrm{kg})$

V Volume of cylinder $\left(\mathrm{m}^{3}\right)$

$\mathrm{V}_{0} \quad$ Clearance volume $\left(\mathrm{m}^{3}\right)$

$V_{c} \quad$ Swept volume of Otto cycle $\left(\mathrm{m}^{3}\right)$ 
$\mathrm{V}^{\prime} \quad$ Swept volume of Miller cycle $\left(\mathrm{m}^{3}\right)$

W Net cycle work $(\mathrm{kJ} / \mathrm{kg})$

$\mathrm{Y}_{\mathrm{NOx}}$ NOx emission quantity (ppm)

Compression ratio

м Compression ratio of Miller Cycle. It is the ratio of the cylinder volume between the piston and cylinder head before and after an effective compression stroke. The stroke is from the moment that the intake valve is closed to the top dead centre (TDC), which is shorter than that of Otto cycle.

Expansion ratio of Miller Cycle. It is the ratio of the cylinder volume between the cylinder head and piston before and after an effective expansion stroke. It starts from the TDC to the BDC (bottom dead centre). It is equal to that of Otto cycle.

$\eta_{\mathrm{b}} \quad$ Engine brake thermal efficiency:

$\eta_{\mathrm{th}} \quad$ Cycle thermal efficiency of engine

$\eta_{\mathrm{tFA}} \quad$ Engine fuel-air-cycle efficiency

\section{Subscripts}

$0,1,2,3,4,5$, - different points of Otto cycle

1a, 2a, 3a, 4a, 5a, - different points of Miller cycle

\section{Introduction}

In the last several decades since 1960's, the environmental problems caused by the human activities have been seen, such as global warming and worse air pollutions.

This trend has aroused the public awareness to protect the environment on the earth. This has spread in to all sectors of life with new legislation's being formed as a result. The engine industry has taken a series of measures to improve the engine emissions and to comply with the continued restrictions on the quality and quantity of emissions. The need to comply with emissions legislation means that it is always appropriate to 
investigate ways of reducing emissions without compromising engine efficiency and increasing the costs of manufacturing of engines.

The emissions from petrol engines mainly are: hydrocarbon (HC), carbon monoxide (CO), carbon dioxide $\left(\mathrm{CO}_{2}\right)$ and nitrogen oxides (NOx). Among them, NOx is the most harmful emissions. It contributes to the formation of Ozone $\left(\mathrm{O}_{3}\right)$, and other irritating smog components, which cause the urban summer eye and nose, etc.

The formation of NOx in engines, are greatly influenced by the following factors. First of all, the combustion flame temperature; secondly, the duration of high temperature, and thirdly, the oxygen content in the flames. Among these factors, flame temperature is the key factor. The higher of combustion temperature of flame in the engine is, the higher NOx emission will be.

In order to reduce NOx emissions from engines, currently there are two main ways: one is after-treatment that uses catalysts to react with the NOx emitted from the engines; another is in-cylinder treatment that reduces the formation of NOx in the cylinders of engines. For the first method, it reduces NOx emissions effectively, but it increases the cost of the engine manufacturers and then customers for the converter and catalysts, and the additional space required for fixing the converter on vehicles. Consequently, the aims to apply in-cylinder treatment measure are always pursued.

Miller Cycle was first proposed by R H Miller In 1947[1]. The proposal was the use of early intake valve closing (EIVC) to provide internal cooling before compression so as to reduce compression work. Miller further proposed increasing the intake 
pressure to compensate for the reduced charge due to the early intake valve closing [2]. The Miller Cycle is a cold cycle which has allowed in the past an increase in engine performance with an upraising of the knocking threshold. At this time, Miller Cycle focused on improving the thermal efficiency of engine [3-9].

Since Miller cycle is a cold cycle, making use of this characteristic of Miller cycle to achieve lower combustion temperature may result in lower NOx formation in engine cylinder and then lower NOx emissions. A previous experimental study for the application of Miller cycle to reduce NOx emissions has shown the effect of the reduction of NOx emissions [10]. But a thermodynamic investigation has not been carried out yet. The aim of this study is to continue the investigation on the base of the experimental results, to carry out a thermodynamic analysis of the application of Miller cycle on petrol engine to reduce NOx emissions.

\section{The Concept of Miller Cycle}

\subsection{The basic characteristic of Miller Cycle}

The characteristic of Miller cycle is: The effective compression stroke of engine is shorter than the expansion stroke. Fig 1 illustrates the comparison of standard Otto cycle to Miller cycle; the P-V diagrams are also shown in the figure. Assuming the pressure in cylinder at the starting point 0 is $\mathrm{P}_{0}$, the volume is $\mathrm{V}_{0}$, the swept volume of cylinder for Otto Cycle is $\mathrm{V}_{\mathrm{c}}$, for Miller Cycle is $\mathrm{V}_{\mathrm{c}}$. 
For Otto cycle, shown in Fig 1 (a), the work process is: intake stroke 0-1, compression stroke 1-2, combustion and expansion stroke 2-3-4, and exhaust stroke 4-1-0, where the compression ratio is identical to the expansion ratio, a higher expansion ratio causes a higher compression ratio and results in harmful engine knocking while the compression ratio excesses $10 \sim 12$.

For Miller cycle as shown in Fig.1 (b), however, allows the compression and expansion ratios to be preset independently. The work process is: intake stroke $0-1 \mathrm{a}-1$; then an additional "intake blow back" process 1-1a, which is the main difference between Miller cycle to Otto cycle; compression stroke 1a-2; combustion and expansion stroke 2-3-4-4a; exhaust stroke 4a-1-1a-0. From the P-V diagram of Miller cycle, higher engine efficiency is expected with increased expansion ratio, while engine knocking can be avoided by reducing the effective compression ratio.

\subsection{The basic mechanism of Miller Cycle to reduce NOx emissions}

As mentioned above, the main cause of NOx formation is the combustion flame temperature in the cylinder during the combustion process. Utilizing the characteristic of Miller cycle, to reduce the compression pressure and the compression temperature at the end of compression stroke (at the point 2 in P-V diagram), therefore to achieve lower combustion temperature at the end of combustion process (point 3 in $\mathrm{P}-\mathrm{V}$ diagram), then lower NOx formation and emissions may be expected. This is the thermodynamic basis of applying Miller cycle to reduce NOx emission from petrol engines. 
Fig 2 illustrates the P-V diagram of this concept of Miller cycle. Cycle 0 - 1 - 2 - 3 - 4 - 1 - 0 is the standard Otto cycle. Cycle $0-1-1 \mathrm{a}-2 \mathrm{a}-3 \mathrm{a}-4 \mathrm{a}-1-0$ is the Miller cycle. The intake valve keeps open (closes later than Otto cycle) during a portion of compression stroke. Some of the intake air into cylinder is rejected into the intake pipe. Then the amount of intake air into cylinder is relatively less than Otto cycle and this reduces the effective compression ratio. At the end of the compression stroke, the pressure and temperature in cylinder are lower than those of standard Otto cycle; and then during the combustion stroke, the combustion temperature is then lower, this may result in less NOx formation in the cylinder; finally, in the exhaust stroke it leads to less NOx emissions.

\subsection{The methods to realize Miller Cycle}

There are three main methods to realize Miller Cycle [5 - 8]: (a) Using a rotating valve between the intake pipe and intake valve on cylinder head to control the quantity of intake air - Early Rotary-Valve Closing (ERVC); (b) Closing the intake valve before the termination of the intake stroke - Early Intake Valve Closing (EIVC); (c) Keeping intake valve open during a portion of the compression stroke, thus rejecting part of the charge and reducing the net compression ratio - Late IntakeValve Closing (LIVC - as shown in Fig 2). This version of LIVC Miller cycle is applied to the investigation. A schematic valve timing diagram of LIVC Miller cycle is shown in Fig 3.

\section{Experimental results from previous engine tests}


Experimental studies to investigate and to compare the performance and emission characteristics of the original engine (Otto cycle) to those of Miller cycle have been carried out. The detail results are presented in the previous published paper by the author [10]. The engine used for the experimental tests is a Rover " $\mathrm{K}$ " series 16 -valve twin-camshaft petrol engine, type K-16 1400TBI, made by the Rover Group Ltd in 1991. It has $1397 \mathrm{~cm}^{3}$ displacement, compression ratio 9.5 , maximum power $70.8 \mathrm{~kW}$ (95 hp) $/ 6250 \mathrm{rev} / \mathrm{min}$ (torque $106.7 \mathrm{Nm}$ ), maximum torque $124 \mathrm{Nm} / 4000 \mathrm{rev} / \mathrm{min}$, equipped for Rover $200 \& 400$ series cars. The schematic diagram of the test rig is showed in Fig 4.

For the experimental study, two versions of LIVC Miller cycle were designed, realized and tested in the tests: Miller cycle 1, intake valve closed 15 degrees later than that of original Otto cycle, the Miller cycle ratio is 0.95 . Miller cycle 2, intake valve closed 30 degrees later than that of original Otto cycle, the Miller cycle ratio is 0.90 .

Figure 5 and Fig 6 show the test results of exhaust temperature and NOx emissions of the petrol engine at three different cycles on different engine speed and load. Fig 5 presents the comparison of the exhaust temperatures at the outlet of exhaust manifold. The results showed that the exhaust temperatures of Miller cycles at different engine speed were all lower than that of standard Otto cycle. For Miller cycle 1, the temperature differences were between $20{ }^{\circ} \mathrm{C}$ to $62{ }^{\circ} \mathrm{C}$, compared with those of Otto Cycle. The maximum temperature difference was $11 \%$. For Miller cycle 2, compared with Otto cycle, the temperature differences were between $45^{\circ} \mathrm{C}$ to $112^{\circ} \mathrm{C}$. The maximum temperature difference was 19\%. Fig 6 shows the test results of NOx 
emissions and the comparison of different cycles. For the cycles tested, the NOx emissions of Otto cycle were the highest one, from 620 ppm to $2610 \mathrm{ppm}$. For Miller Cycle 1, the NOx emissions were less than that of Otto cycle, the reductions were from $130 \mathrm{ppm}$ to $665 \mathrm{ppm}$. The maximum difference was 51\%. For Miller cycle 2, the NOx emissions were much less than Otto cycle, the reductions were from $360 \mathrm{ppm}$ to $850 \mathrm{ppm}$; the maximum difference was $58 \%$.

From the experimental results above, the relation of engine exhaust temperature versus NOx emissions at different engine speed; the relation of engine exhaust temperature versus Miller cycle ratio; and a relation of engine NOx emissions versus Miller cycle ratio are found, which are showed in the following figures.

Fig 7 presents the relation of engine exhaust temperatures versus NOx emissions at different engine speed. The results show that when the exhaust temperatures were low, the NOx emissions were low; when the exhaust temperatures were higher, the NOx emissions were higher when the engine run at the same speed.

Fig 8 (a) shows the relation of exhaust gas temperature versus Miller cycle ratio at the engine full load. Fig 8 (b) presents the relation of NOx emission versus Miller cycle ratio. For Otto cycle, Miller cycle ratio was 1; exhaust gas temperature was $808{ }^{\circ} \mathrm{C}$; the relevant NOx emission was 2610 ppm. For Miller cycle 1, the Miller cycle ratio was 0.95 , exhaust gas temperature was $788^{\circ} \mathrm{C}$, the relevant NOx emission was 2400 ppm. For Miller cycle 2, the Miller cycle ratio was 0.90, exhaust gas temperature was $752{ }^{\circ} \mathrm{C}$, the relevant NOx emission was $1420 \mathrm{ppm}$. This shows that the lower of exhaust temperature is, the less of the NOx emission is, at the same engine speed. 
Fig 8 (c) shows the relation of engine thermal efficiency versus the Miller cycle ratio. It can be seen that the engine thermal efficiency increased when the Miller cycle ratio lowered down. In contrast, for the engine power output, it was reduced when the Miller cycle ratio of the engine dropped down, as shown in Fig 8 (d). The reason is because the intake stroke of Miller cycles is shorter, then air and fuel input to the engine cylinder is less, therefore the heat energy input to the engine is less. The less heat energy input results in the less power output in spite of the increase of the engine thermal efficiency.

\section{Thermodynamic analysis of Miller cycle}

The following is the thermodynamic analyses of the LIVC version of Miller cycle, compared to that of Otto cycle.

\subsection{Otto cycle}

As shown in Fig 2, the petrol engine working on the standard Otto cycle has the following process: intake, compression, combustion and expansion, and exhaust. The equations for the cycle calculation can be found in literatures [11] and are not listed here.

\subsection{Late Intake Valve Closing Miller Cycle}


As also shown in Fig 2, the petrol engine working on the Late Intake Valve Closing

Miller cycle has the following process:

Intake stroke, constant pressure suction process $0-1$,

$$
\mathrm{P}_{1}=\mathrm{P}_{0}=\mathrm{P}_{\mathrm{atm}} ; \quad \mathrm{T}_{1}=\mathrm{T}_{0}=\mathrm{T}_{\mathrm{atm}}
$$

Intake blowback process $1-1 \mathrm{a}$,

$$
\mathrm{P}_{1 \mathrm{a}}=\mathrm{P}_{1} ; \quad \mathrm{T}_{1 \mathrm{a}}=\mathrm{T}_{1}
$$

Compression stroke $1 \mathrm{a}-2 \mathrm{a}$, isentropic compression process $1 \mathrm{a} \rightarrow 2 \mathrm{a}$,

$$
\begin{aligned}
& \frac{P_{2 a}}{P_{1 a}}=\left(\frac{V_{1 a}}{V_{2 a}}\right)^{k} \\
& \frac{T_{2 a}}{T_{1 a}}=\left(\frac{V_{1 a}}{V_{2 a}}\right)^{k-1}=\varepsilon_{M}{ }^{k-1}
\end{aligned}
$$

Where $\boldsymbol{\varepsilon}_{\mathbf{M}}$ is the compression ratio of Miller Cycle:

$$
\varepsilon_{M}=\frac{V_{1 a}}{V_{2 a}}
$$

In order to compare the difference between Miller cycle and Otto cycle, a concept of "Miller Cycle Ratio $r_{\mathrm{M}}$ " [12] is adopted to describe the difference.

$$
\varepsilon_{M}=r_{M} \varepsilon
$$

When $r_{M}=1, \varepsilon_{M}=\varepsilon$, the Miller cycle is identical with the Otto cycle.

Combustion and expansion stroke $2 \mathrm{a}-3 \mathrm{a}-4 \mathrm{a}$ :

Constant volume heat addition process $2 \mathrm{a} \rightarrow 3 \mathrm{a}$ 


$$
\begin{aligned}
& \frac{P_{3 a}}{P_{2 a}}=\frac{T_{3 a}}{T_{2 a}} \\
& q_{i n}=\left(u_{3}-u_{2}\right)=c_{v}\left(T_{3 a}-T_{2 a}\right)
\end{aligned}
$$

Isentropic expansion process $3 \mathrm{a} \rightarrow 4 \mathrm{a}$,

$$
\begin{aligned}
& \frac{P_{4 a}}{P_{3 a}}=\left(\frac{V_{3 a}}{V_{4 a}}\right)^{k} \\
& \frac{T_{4 a}}{T_{3 a}}=\left(\frac{V_{3 a}}{V_{4 a}}\right)^{k-1}=\frac{1}{\varepsilon_{e}^{k-1}}
\end{aligned}
$$

Where the expansion ratio of Miller cycle is not the same as the compression ratio, which is:

$$
\varepsilon_{e}=\frac{V_{4 a}}{V_{3 a}}=\frac{V_{4}}{V_{3}}
$$

Exhaust stroke $4 a-1-0$ :

Constant volume heat rejection process $4 \mathrm{a} \rightarrow 1$,

$$
\begin{aligned}
& \frac{P_{4 a}}{T_{4 a}}=\frac{P_{1}}{T_{1}} \\
& q_{\text {out }}=\left(u_{4 a}-u_{1}\right)=c_{v}\left(T_{4 a}-T_{1}\right)
\end{aligned}
$$

Constant pressure exhaust process $1 \rightarrow 0$,

$$
\mathrm{P}_{5 \mathrm{a}}=\mathrm{P}_{1}=\mathrm{P}_{0}
$$

The exhaust gas expands to the atmospheric pressure when the exhaust valve opens, the exhaust temperature can be seen as the gas temperature at the state 5a (Fig 2), which may be determined from reversible adiabatic relationships as 


$$
\mathrm{T}_{\mathrm{exh}}=\mathrm{T}_{5 \mathrm{a}}=T_{3 a}\left(\frac{P_{5 a}}{P_{3 a}}\right)^{(k-1) / k}
$$

Net cycle work is

$$
W=m\left(u_{3 a}-u_{4 a}\right)-m\left(u_{2 a}-u_{1}\right)
$$

The engine indicated power $\mathrm{Pi}(\mathrm{kW})$ produced by the engine is

$$
\begin{aligned}
& \mathrm{Pi}=\mathrm{m} \cdot \mathrm{W} \cdot \mathrm{cps} \cdot \mathrm{i} \\
& m=\frac{P_{1} V_{1}}{R T_{1}}
\end{aligned}
$$

The brake power produced by the engine is:

$$
\mathrm{P}_{\mathrm{e}}=\boldsymbol{\eta}_{\mathrm{b}} \cdot \mathrm{Pi}
$$

Cycle thermal efficiency:

$$
\eta_{t h}=\frac{W}{Q_{i n}}=\frac{\left(u_{3 a}-u_{4 a}\right)-\left(u_{2 a}-u_{1}\right)}{\left(u_{3 a}-u_{2 a}\right)}=1-\frac{\left(T_{4 a}-T_{1}\right)}{\left(T_{3 a}-T_{2 a}\right)}
$$

For a real engine, its cycle can be described as a kind of fuel-air-cycle [11], the corresponding efficiency, $\eta_{\mathrm{tFA}}$ is:

$$
\boldsymbol{\eta}_{\mathrm{tFA}} \approx 0.75 \boldsymbol{\eta}_{\mathrm{th}}
$$

The brake thermodynamic efficiency of an actual engine, $\boldsymbol{\eta}_{\mathrm{b}}$, is roughly 0.8 times that of the fuel-air cycle [11], that is:

$$
\boldsymbol{\eta}_{\mathrm{b}} \approx 0.80 \boldsymbol{\eta}_{\mathrm{tFA}}
$$

\section{Results from the thermodynamic analyses}


A computation based on the above thermodynamic analyses is carried out to calculate the engine performance for Otto cycle and Miller cycles. The ranges of Miller cycle ratio for the calculation were selected from 0.9 to 1.0 . The calculation results are presented in Figure 8.

As for the calculation of NOx emissions, Wunning, J.G. [13 -14] pointed out that there are three predominantly mentioned sources of nitric oxides from combustion processes: prompt NO, fuel NO and thermal NO. Whereof the thermal NO-formation, described by the 'Zeldovich-mechanism' is the most relevant source for the combustion of clean fuels. The NOx formation is strongly influenced by the combustion temperatures. Because of that strong temperature influence, most NOreducing techniques try to cut off peak temperatures, keep the residence time in high temperature areas low, and avoid high oxygen concentration in these areas. Webster, T. found that there was a linear relation between the NOx emissions and flame temperatures in burners [15]: the higher the flame temperature is, the more NOx emissions is. Mancini, M. and Weber, R. found the similar results as that of Webster's. They found that there was a relation between NOx emissions and flame temperature [16]: NOx $[\mathrm{ppm}]=0.31^{*} \mathrm{~T}_{\text {comb. }}\left[{ }^{\circ} \mathrm{C}\right]-181$. Milani, A. and Saponaro, A. found that the thermal NO formation is extremely sensitive to process temperature and presented a figure showed that NOx emissions are increased when the process temperature increased [17]. In this study, the exhaust temperatures were measured. The exhaust temperature is directly related to the combustion temperature and is good representation of the combustion temperatures. Referring to the recommendation from literatures, by applying the exponential fitting to the previous experimental results at 
different engine speeds $\mathrm{n}(\mathrm{r} / \mathrm{min})$, empirical formulae of NOx emission versus exhaust temperature are drawn, which is (as shown in Fig 7):

$$
Y_{N O x}=x_{1} \mathrm{e}^{x_{2} \mathrm{~T}_{\mathrm{exh}}}
$$

Where $\mathrm{Y}_{\text {NOx }}$ is the NOx emissions $(\mathrm{ppm}), \mathrm{T}_{\mathrm{exh}}$ is the temperature of the exhaust gas $\left({ }^{\circ} \mathrm{C}\right) . x_{1}$ and $x_{2}$ are coefficients, which are listed in Table 1 . The validity range of the empirical correlation was from 399 to $808^{\circ} \mathrm{C}$. The reliability of the equation is shown in the form of the square of the correlation coefficient (R-squared value) in Table 1.

The simulation results of exhaust temperature versus the Miller cycle ratio are presented in Fig 8 (a). From the figure, it can be seen that the exhaust temperature is dropped as long as the Miller cycle ratio is reduced. The lower the Miller cycle ratio $r_{\mathrm{M}}$ is, the lower the exhaust temperature is. While the Miller cycle ratio $r_{\mathrm{M}}=1$, this is Otto cycle, the exhaust temperature $\mathrm{T}_{\mathrm{exh}}$ equals to $808^{\circ} \mathrm{C}$; when $r_{\mathrm{M}}=0.9, \mathrm{~T}_{\mathrm{exh}}=730$ ${ }^{\circ} \mathrm{C}$.

Fig 8 (b) shows the simulation results of NOx emissions versus the Miller cycle ratio $r_{\mathrm{M}}$. When the Miller Cycle ratio $r_{\mathrm{M}}=1$, this is Otto cycle, the NOx emissions reach the highest value, $2826 \mathrm{ppm}$; when $r_{\mathrm{M}}=0.9$, the NOx emissions are $1600 \mathrm{ppm}$. The figure shows that the lower the Miller cycle ratio is, the less the NOx emissions are. Similar results can be found from the other researches [9, $16-18]$. 
The simulation results of engine thermal efficiency versus the Miller cycle ratio are shown in Fig 8 (c). While the Miller cycle ratio $r_{M}=1$, this is Otto cycle, the engine thermal efficiency $\eta_{\mathrm{b}}$ is the lowest value, $23.50 \%$, when $r_{\mathrm{M}}=0.9, \eta_{\mathrm{b}}=27.40 \%$, which is the highest value. This result shows that Miller cycle can improve the thermal efficiency of engine, which is the original idea that Mr Miller to propose the cycle in 1947. Similar results can be found in the other researches [16 - 23].

The simulation results of engine power output versus the Miller cycle ratio are presented Fig 8 (d). The figure shows the trend that the engine power output reduces when the Miller cycle ratio lowers down. When $r_{\mathrm{M}}=0.9, \mathrm{P}_{\mathrm{e}}=54.14 \mathrm{~kW}$. While the Miller cycle ratio $r_{M}=1$, this is Otto cycle, the engine power output $\mathrm{P}_{\mathrm{e}}$ is the highest, reaches to $59.60 \mathrm{~kW}$.

\section{Conclusions}

The objective of this study is realized. The results from the thermodynamic analyses based on the previous experimental results demonstrate that applying Miller cycle to petrol engine is able to reduce NOx emissions.

The results from the computation show that the Miller cycle ratio is the main factor to control the combustion temperature, exhaust temperature and then to control the NOx emissions from the petrol engine. The reduction of Miller cycle ratio results in the reduction of the combustion temperature then exhaust temperature, and the reduction of NOx emissions. 
The analytic results also show that the reduction of Miller cycle ratio results in the increase of engine thermal efficiency, but it causes the reduction of engine power output.

The results from the thermodynamic analyses are a good explanation for the previously experimental results. The results may be able to apply to the other petrol engines for the similar studies.

Further work is needed to optimise the effect of Miller cycle such as: A detailed study to select the optimising point of Miller cycle ratio, i.e. optimising the parameters of the Late Intake Valve Timing of the engine, to find the best operation parameters for both NOx emission reduction and the engine power output. Further experimental and analytical studies are also necessary to find out the mechanism of Miller cycle to reduce NOx emissions in more details.

\section{Acknowledgements}

The support of the Faculty of Computing, Engineering and Technology of Staffordshire University of UK is greatly appreciated, so too is the support of Guangxi University of China.

\section{References}

[1] Miller, R. H.; Supercharging and Internal Cooling Cycle for High Output, Transactions of ASME 69, 1947, p.453-457 
[2] Miller, R. H., Lieberherr, H.U.; The Miller Supercharging System for Diesel and Gas Engines Operating Characteristics, CIMAC, 1957, Proceedings of the 4th International Congress on Combustion Engines, Zurich, Jun 15-22, 1957, p. 787 - 803

[3] Okamoto, K., Zhang, F.R., Shimogata, S., Shoji, F., Kanesaka, H. and Sakai H., Study on Miller Cycle Gas Engine for Co-generation Systems - Effect of Miller Cycle on the Performance of Gas Engine, SAE Special Publications, 1996, Vol. 1171, p $125-136$

[4] Thring, R.H., The Flexible Diesel Engine, Proceedings of the International Congress and Exposition, Detroit, USA, 1990, SAE Paper No. 900175, SAE Special Publications, 1990, p. $484-492$

[5] Clarke, D. and Smith, W. J.; Simulation, implementation and analysis of the Miller cycle using an inlet control rotary valve, Variable valve actuation and power boost, SAE Special Publications, 1997, Vol. 1258 (SAE Paper No. 970336), pp. 61 70

[6] Shimogata, S., Homma, R., Zhang, F.R., Okamoto, K., Shoji, F.; Study on Miller Cycle Gas Engine for Co-generation Systems- Numerical Analysis for Improvement of Efficiency and Power, SAE Paper No.971709, SAE Special Publications, 1997, p. $61-67$

[7] Franca, I.; Miller Cycle - Outline and General Considerations, Diesel Ricerche S.P.A. Technical report, 1996

[8] Okamoto, K., Zhang, F. R., Morimoto, S., Shoji, F.; Development of a Highperformance Gas Engine Operating at a Stoichiometric Condition - Effect of Miller Cycle and EGR-, Proceedings of CIMAC Congress 1998 Copenhagen, 1998, p. 1345 $-1360$ 
[9] Stebler, H., Weisser, G., Horler, H. and Boulouchos, K.; Reduction of NOx Emissions of D.I. Diesel Engines by Application of the Miller-System: An Experimental and Numerical Investigation, SAE Paper No.960844, SAE Special Publications, 1996, p. $1238-1248$

[10] Wang Y.D. and Ruxton, T., An Experimental Investigation of NOx Emission Reduction from Automotive Engine Using the Miller Cycle, Proceedings of ICEF2004, ASME Internal Combustion Engine Division, 2004 Fall Technical Conference, Long Beach, CA, USA, October 24-27, 2004.

[11] Taylor, C. F. The Internal Combustion Engine in Theory and Practice. Vol. 1, and 2, Second Edition, Cambridge, MA: M.I.T. Press, 1985.

[12] Koichi Hatamura, Motoo Hayakawa, Tsuyoshi Goto, Mitsuo Hitomi, A study of the improvement effect of Miller-cycle on mean effective pressure limit for highpressure supercharged gasoline engines, JSAE Review 18 (1997) p.101-106

[13] Wunning, J.G., Flameless Combustion in the Thermal Process Technology, Second International Seminar on High Temperature Combustion, Stockholm, Sweden, 17-18 Jan 2000.

[14] Wunning, J.A. and Wunning, J.G., Flameless oxidation to reduce thermal NOformation, Progress in Energy and Combustion Science, Vol. 23, p.81 - 94, 1997.

[15] Webster, T., Burner Technology for Single Digit NOx Emissions in Boiler Applications, CIBO NOx Control XIV Conference, San Diego, CA, March 13, 2001.

[16] Kesgin U., Study on prediction of the effects of design and operating parameters on NOx emissions from a leanburn natural gas engine, Energy Conversion and Management, Vol. 44, 2003, p.907-921.

[17] Milani, A. and Saponaro, A., DILUTED COMBUSTION TECHNOLOGIES, IFRF Combustion Journal, Article Number 200101, February 2001, ISSN 1562-479X 
[18] Ki-Doo Kim and Dong-Hun Kim, Improving the NOx-BSFC Trade Off of a Turbocharged Large Diesel Engine Using Performance Simulation, Hyundai Heavy Industries Co., Ltd, http://www.ricardo.com/download/pdf/wave improve nox bsfc. pdf

[19] Kesgin, U., Efficiency improvement and NOx emission reduction potentials of two-stage turbocharged Miller cycle for stationary natural gas engines, International Journal of Energy Research, 2005; vol.29: p.189-216.

[20] Mancini, M. and Weber, R., Formation and destruction of nitrogen oxides in combustion of natural gas with high temperature air, Proceedings of the 5th International Symposium on High Temperature Air Combustion and Gasification (HTACG), Yokohama, Japan, October 2002.

[21] Ge, Y., Chen, L., Sun, F., Wu, C., Reciprocating heat-engine cycles, Applied Energy, vol. 81, 2005, p.397-408.

[22] Fukuzawa,Y., Shimoda, H., Kakuhama, Y., Endo, H. and Tanaka, K., Development of High Efficiency Miller Cycle Gas Engine, Mitsubishi Heavy Industries, Ltd. Technical Review Vol.38 No.3 (Oct. 2001), p.146 - 150.

[23] Anderson, M., Assanis, D. and Filipi, Z., First and Second Law Analyses of a Naturally-Aspirated, Miller Cycle, SI Engine with Late Intake Valve Closure, SAE Technical Paper Series 980889, International Congress and Exposition Detroit, Michigan, February 23-26, 1998, p.1-16. 

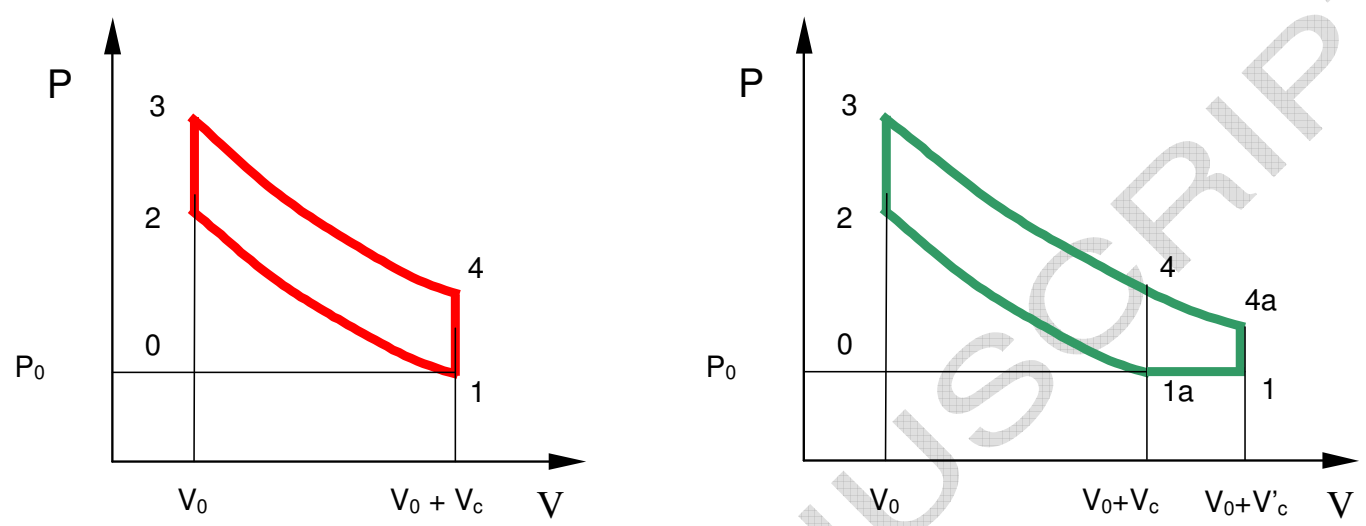

Intake

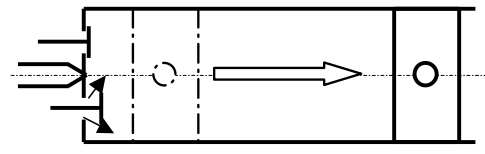

Intake

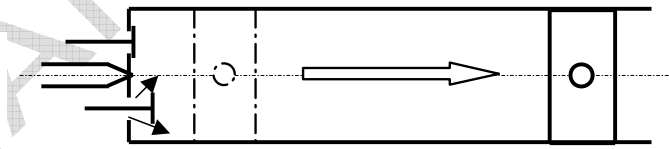

Intake blow

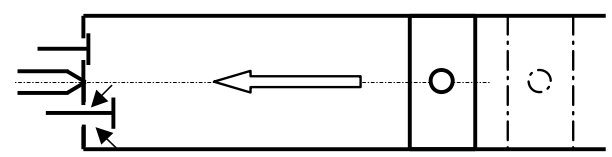

Compression

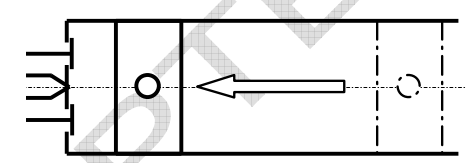

Compression

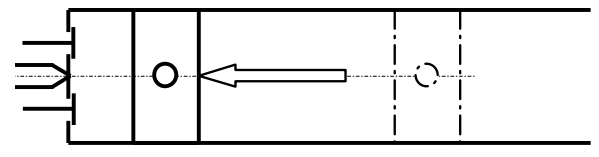

Combustion

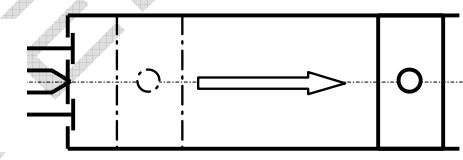

Combustion
\& Expansion

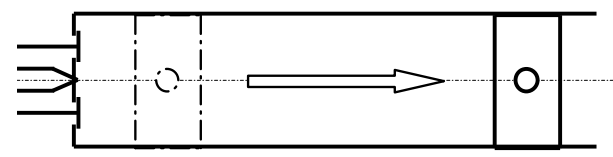

Exhaust

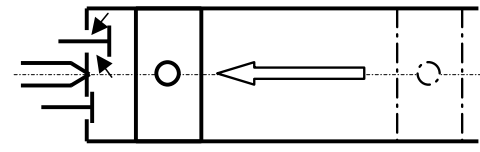

(a) Otto Cycle
Exhaust

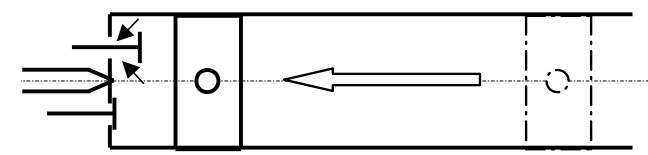

(b) Miller Cycle

Fig 1 A comparison of standard Otto Cycle to Miller Cycle 


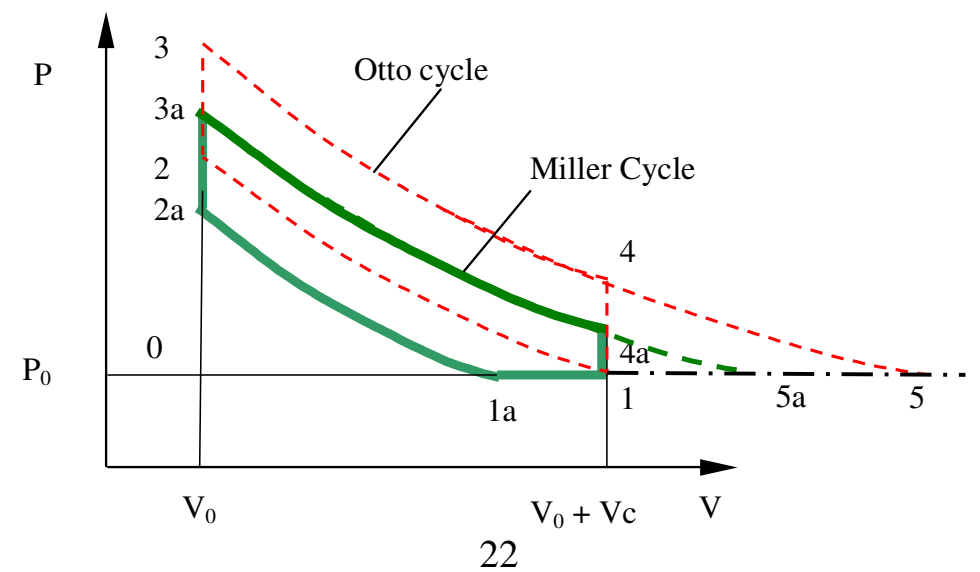

Fig 2 A comparison of P-V diagram of Otto Cycle to Miller Cycle 


\section{ACCEPTED MANUSCRIPT}

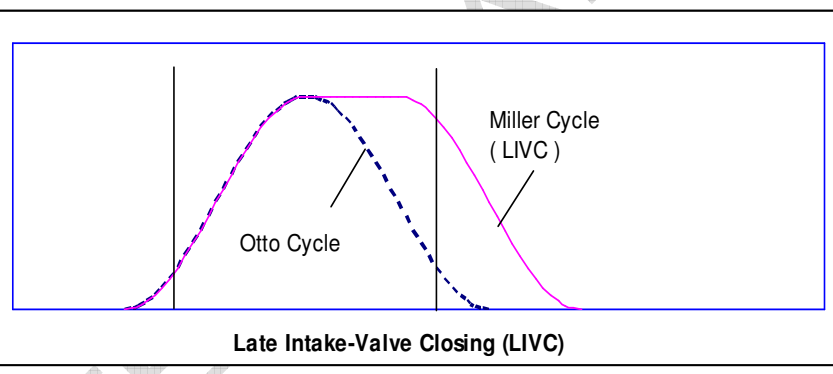

Fig 3 Schematics of Valve Timing of Miller cycle (LIVC) 


\section{ACCEPTED MANUSCRIPT}

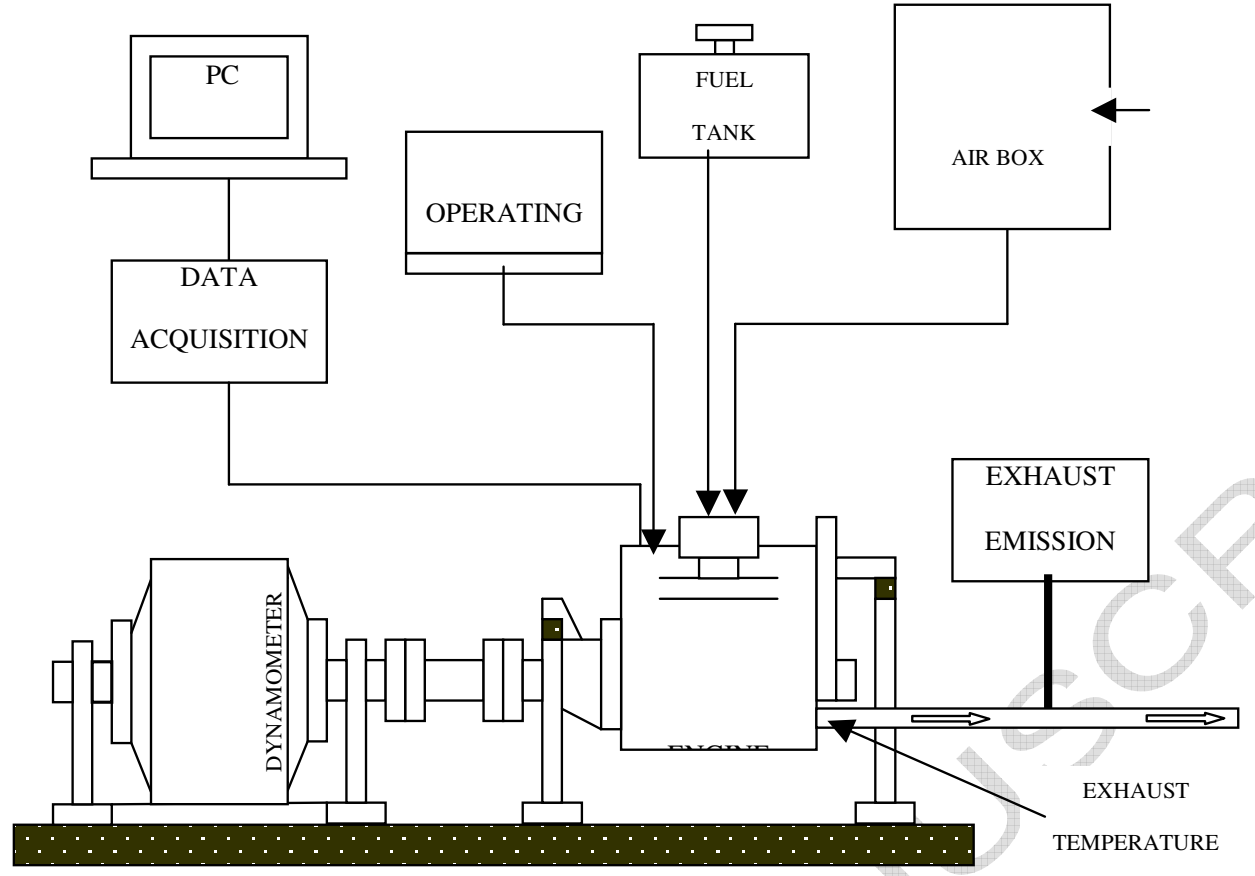

Fig 4 Schematic Diagram of Test Rig

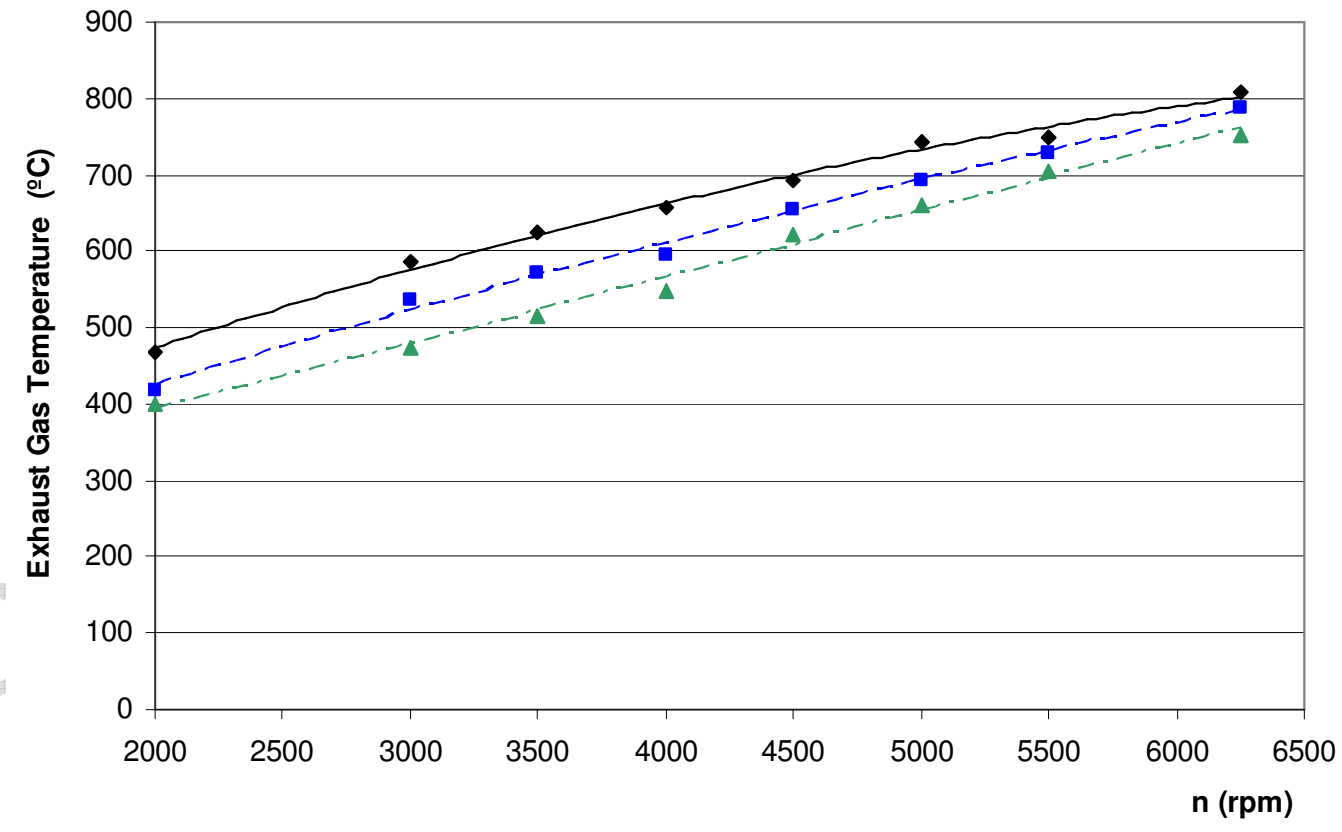

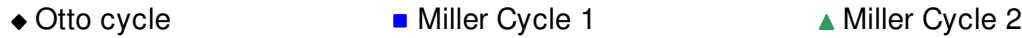

Fig 5 Exhaust Gas Temperature Comparison of Otto Cycle to Miller cycle 


\section{ACCEPTED MANUSCRIPT}

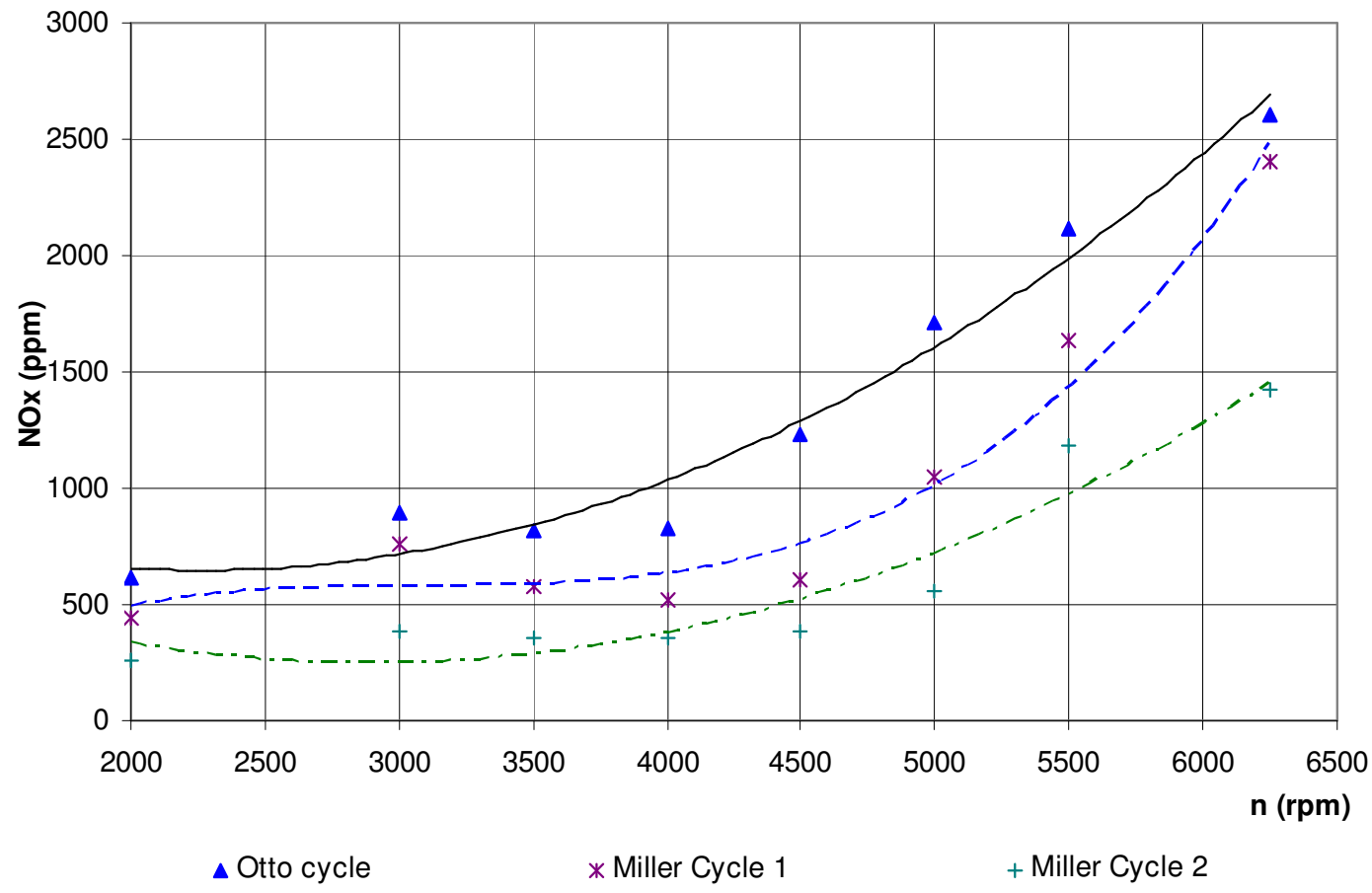

Fig 6 NOx Emissions Comparison of Otto Cycle to Miller cycle 


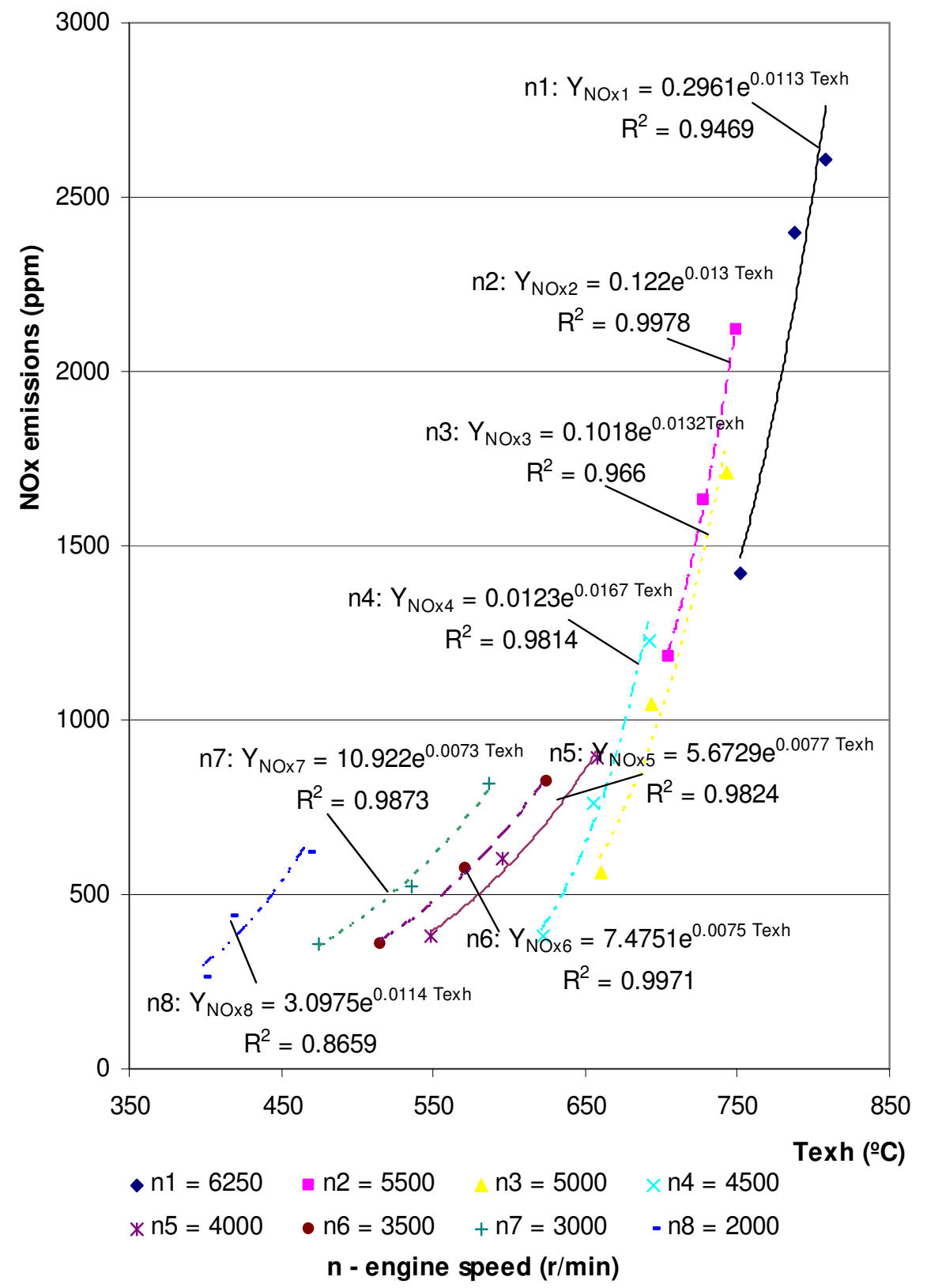

Fig 7 Exhaust Temperature Versus NOx Emissions at different engine speed 


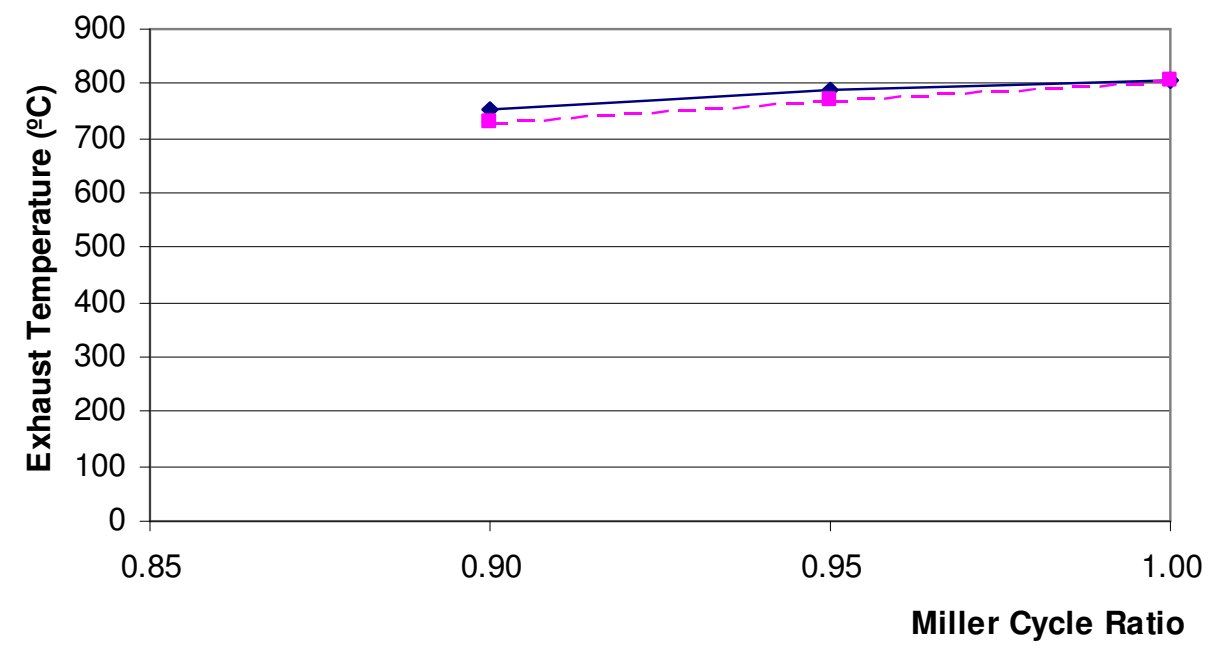

$\longrightarrow$ Experimetal results $-\rightarrow-$ Simulation results

Fig 8 (a) Experimental and simulation results of exhaust temperature Versus Miller Cycle Ratio 


\section{ACCEPTED MANUSCRIPT}

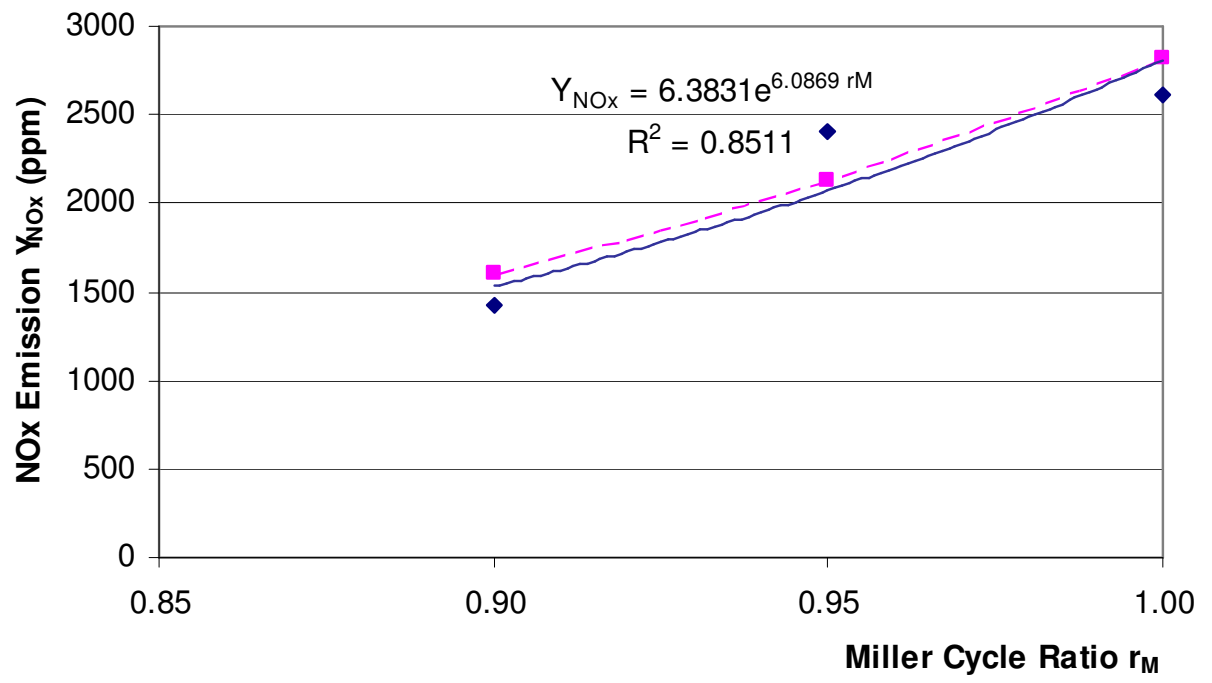

Fig 8 (b) Experimental and simulation results of NOx emissions Versus Miller Cycle Ratio

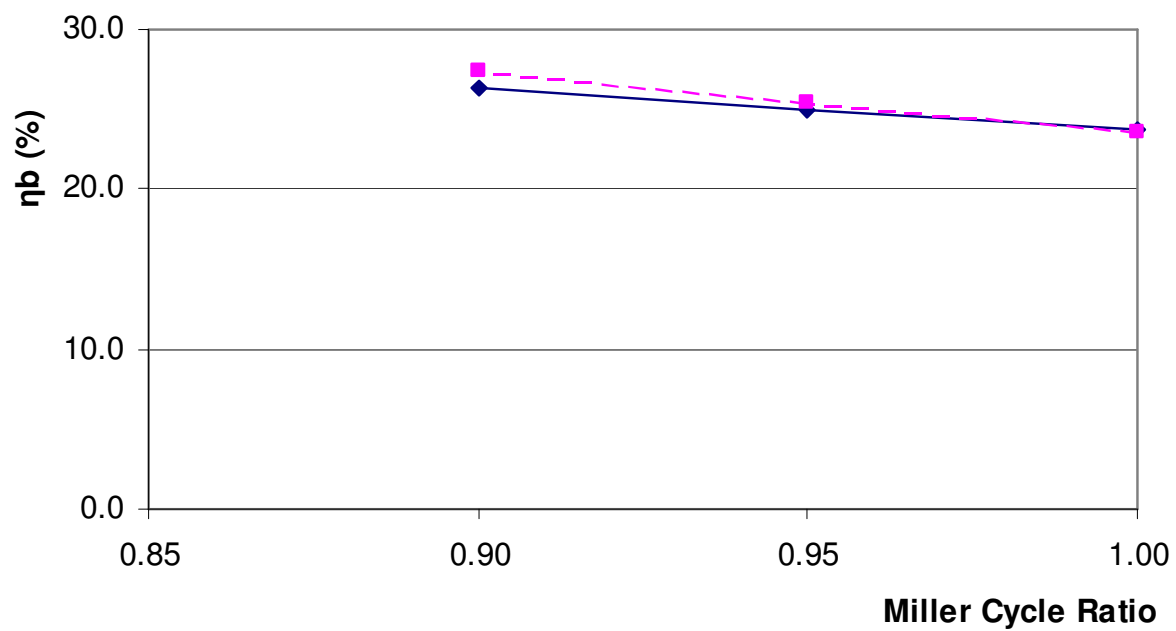

$\longrightarrow$ Experimental results ---- Simulation results

Fig 8 (c) Experimental and simulation results of Engine Thermal efficiency Versus Miller Cycle Ratio 


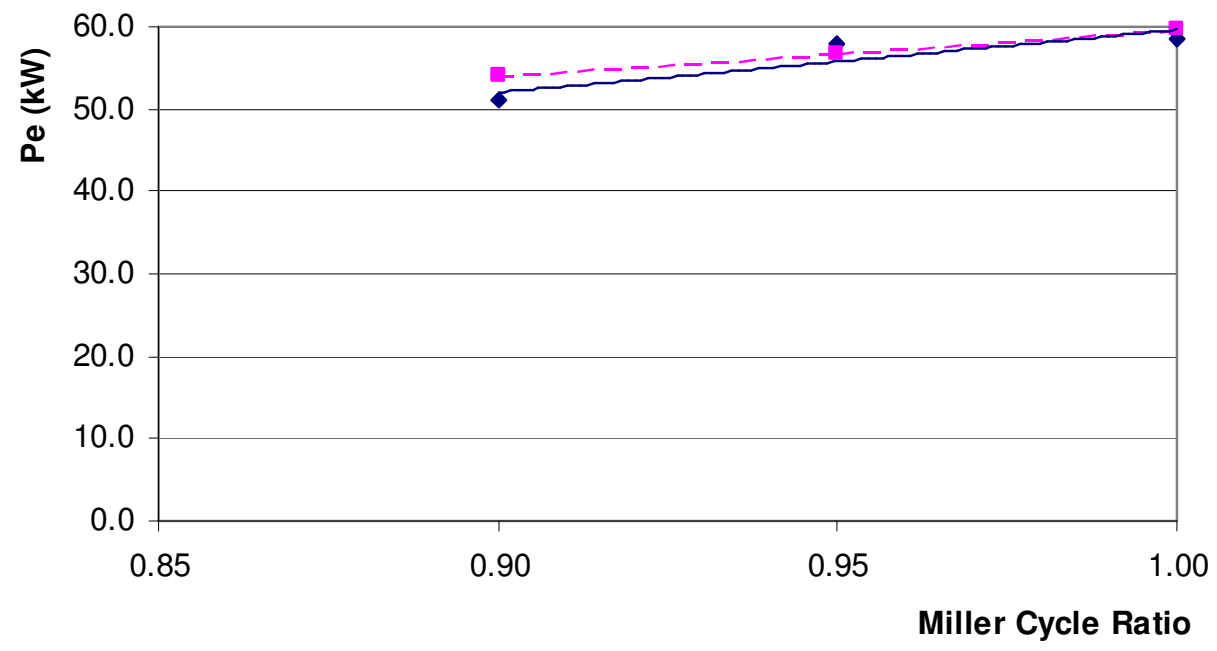

- Experimental results - -- Simulation results

Fig 8 (d) Experimental and simulation results of Engine Power Versus Miller Cycle Ratio 


\section{ACCEPTED MANUSCRIPT}

Table 1 Coefficient $\boldsymbol{x}_{1}, \boldsymbol{x}_{2}$, and R-squared values

\begin{tabular}{|c|c|c|c|}
\hline $\begin{array}{c}\text { Engine speed } \\
(\mathrm{r} / \mathrm{min})\end{array}$ & Coefficient $\boldsymbol{x}_{1}$ & Coefficient $\boldsymbol{x}_{2}$ & $\begin{array}{c}\text { R-squared value } \\
\left(\mathrm{R}^{2}\right)\end{array}$ \\
\hline 6250 & 0.2961 & 0.0113 & 0.9469 \\
5500 & 0.1220 & 0.0130 & 0.9978 \\
5000 & 0.1018 & 0.0132 & 0.9660 \\
4500 & 0.0123 & 0.0167 & 0.9814 \\
4000 & 5.6729 & 0.0077 & 0.9824 \\
3500 & 7.4751 & 0.0075 & 0.9971 \\
3000 & 10.9220 & 0.0073 & 0.9873 \\
2000 & 3.0975 & 0.0114 & 0.8659 \\
\hline
\end{tabular}

